\title{
КРИТЕРІЇ ВИБОРУ УЧНЯМИ ХІМІЧНОГО ФАКУЛЬТАТИВУ
}

Абжалов Р. Р. Критерії вибору учнями хімічного факультативу.

У статті обгрунтовано критерії вибору учнями факультативного курсу з хімії на засадах становлення сучасного уроку та факультативу як форми диференційованого навчання. Зроблено спробу експериментального доведення визначених критеріїв на основі опитування учнів старшої школи.

Ключові слова: хімічний факультатив, форма навчання, критерії вибору, мотиви, хімічні елементи.

Абжалов Р. Р. Критерии выбора учащимися химического факультатива.

В статье обоснованы критерии выбора учащимися факультативного курса по химии в условиях становления современного урока и факультатива как формы дифференцированного обучения. Сделана попытка экспериментального подтверждения выделенных критериев на основании опроса учащихся старшей школы.

Ключевые слова: химический факультатив, форма обучения, критерии выбора, мотивы, химические элементы.

Abzhalov R. R. The criteria of choice by the students of the chemical electives.

The article considers the criteria of choice by the students of the chemical electives in the conditions of formation of a modern lesson and elective course as a form of differentiated training. An attempt is made to the experimental proof of these criteria based on a survey of senior pupils.

Key words: chemical elective course, the form of training, selection criteria, motives, chemical elements.

Факультативне навчання хімії $\epsilon$ важливим інструментом задоволення освітніх потреб учнів. Водночас як форма навчання хімічний факультатив має недостатню реалізацію в навчальному процесі, а саме: проведені дослідження підтверджують непопулярність його серед учнів [1;2]. Часто вибір учнями факультативу $\epsilon$ формальним, що дискредитує його сутність. 3-поміж причин окресленої проблеми виокремлюємо:

- недостатнє дослідження і врахування інтересів учнів до вибору факультативу (що є обов'язковим для цієї форми навчання);

- недостатня увага науковців до питання факультативного навчання хімії;

- недостатня увага адміністрації школи до факультативу як форми навчання на фоні загального перевантаження навчального дня учня;

- недостатні навички організації і проведення сучасних факультативних занять учителями;

- малокомплектність шкіл (зокрема сільських), що зумовлює труднощі в організації факультативної групи; 
- слабка матеріально-технічна база кабінетів хімії задля проведення занять факультативу тощо.

На фоні компетентнісного та особистісно зорієнтованого підходів до сучасної української освіти актуальною проблемою є оновлення методики факультативного навчання хімії і приведення іiі у відповідність вимогам часу. Це стосується як змістового, так і процесуального компонентів конкретних методичних систем факультативного вивчення хімії.

Питання факультативного навчання розробляється в працях вітчизняного дидакта В. Кизенка [7]. Організація факультативних занять у школі, зазначає науковець, відбувається на засадах становлення сучасного уроку [7, с. 23]. Факультативні заняття, як і уроки, можуть бути різних типів і мати свою структуру. Чільне місце відводиться факультативним заняттям, присвяченим узагальненню й систематизації знань, тобто створення із розрізнених понять, закономірностей i законів певної системи [7, с. 24]. Погоджуємось 3 думкою автора в тому, що на факультативних заняттях варто привертати особливу увагу закріпленню знань, їх розвитку, відпрацюванню в різних практичних ситуаціях.

Особливими чинниками, які впливають на вибір методів навчання на факультативах, згідно з думкою В. Кизенка, є врахування запитів і побажань учнів, їхні індивідуальні особливості й мотиви, що $\epsilon$ більш можливим, ніж на обов'язкових заняттях [7, с. 25]. Стосовно форм занять наголосимо на тому, що:

- вони повинні активізувати діяльність учнів (диспути, конференції, практичні заняття тощо);

- у виборі форм занять повинні брати участь учні [7, с. 25].

Сучасні підходи до уроку як форми навчання розроблено у працях українських та російських науковців. Роботу О. Пометун та Л. Пироженко присвячено впровадженню інтерактивних технологій на сучасному уроці. Автори вказують на те, що робота учнів у групах і парах, взаємонавчання учнів у парах змінного складу сприяють досягненню позитивних результатів [8, с. 13].

Обгрунтовує урок як організаційну форму навчання, доводить іiі позитивні риси В. Бондар. Автор підкреслює особливу роль учителя, яка не зменшилася 3 часів виникнення класно-урочної системи: «учителя як представника старшого покоління, активного носія соціального досвіду не можуть замінити ніякі засоби навчання: ні книга, ні комп'ютер, ні засоби масової комунікації» [5, с. 101]. Водночас розвиток сучасного уроку повинен реалізовуватись 3 урахуванням новітніх досягнень науки, техніки, культури, педагогічної технології, інноваційної педагогічної практики [5, с. 102].

Науковці М. Чепіль i Н. Дунник указують на те, що головні процеси в комп'ютерних освітніх технологіях - це обмін знаннями, їх накопичення i передавання [10, с. 105]. Уважаємо, що саме там, де комп'ютер полегшить рутинну працю з інформацією, його необхідно застосовувати. Основними завданнями медіаосвіти, на думку авторів, є підготовка учнів до життя в інформаційному суспільстві; формування в них уміння користуватись інформацією в будь-якому вигляді, здійснювати комунікації, усвідомлювати наслідки впливу на людину засобів інформування [10, с. 106].

Російським науковцем А. Хуторським розроблено критерії сучасного уроку. Автор зазначає, що сучасний урок - урок, який відповідає часу, зокрема сучасному стану суспільства, держави, науки, всіх сфер буття, а головне учасників уроку вчителя й учнів. На думку А. Хуторського, сучасний урок - це урок самореалізації 
учня, урок створення освітньої продукції, урок розвитку компетентностей, урок комунікацій тощо [9].

Ураховуючи вказане вище, ми розробили критерії вмотивованого вибору учнями факультативу 3 хімії, які можуть слугувати орієнтиром для педагогів i, зокрема, вчителів хімії.

Mema cmammi- обгрунтувати критерії вмотивованого вибору учнями факультативу з хімії.

Критерій визначається як ознака, на основі якої здійснюється оцінка чогось [6, c. 245]. Розглянемо змістово-цільові й технологічні компоненти хімічних факультативів із позицій учня, який обирає факультатив. Мотиви вибору можуть бути такими:

1. Займатись изікавою (у плані пізнання) $і$ корисною (для себе й інших) справою. Інтерес до пізнання нового $є$ внутрішньою потребою людини. Інтерес до хімічних речовин i явищ, як показує практика, притаманний учням 3 різним рівнем навчальних досягнень. Важливими перешкодами задля вибору учнями факультативу, вважаємо, є:

- недостатні можливості школи як організаційно-методичного, так і матеріального характеру для повноцінного пізнавального процесу;

- знижений інтерес до навчання, пов'язаний 3 альтернативними видами діяльності учнів у їх вільний час, здебільшого, які передбачають сприйняття, а не активні розумові дії (комп'ютерні ігри, мультимедіа, спілкування за допомогою мережі інтернет).

Ми дослідили наявність інтересу до факультативного вивчення старшокласниками такого питання, як хімічні елементи в організмі людини. В опитуванні брали участь 35 учнів 10-11 класів Червоненської ЗОШ I-III ступенів Сумської районної ради Сумської області та Успенської ЗОШ I-III ступенів Буринського району Сумської області.

Опитування проводилось за питанням анкети: Якби мені запропонували обрати факультативний курс для вивчення «Хімічні елементи в організмі людини», то я обрав би його тому, щзо (табл.1).

Таблиця 1

\section{Варіанти відповідей учнів на питання анкети}

\begin{tabular}{|c|c|c|}
\hline $\begin{array}{lr}\text { a) Мені цікаво дізнатися } \\
\text { про роль } \\
\text { елементів вічния } \\
\text { організмі, як } \\
\text { нього вони до } \\
\text { діють прдхояя } \\
\text { надлишку } \\
\text { нормальному } \\
\text { тощо }\end{array}$ & $\begin{array}{l}\text { б) Це корисно для } \\
\text { власного здоров'я } \\
\text { безпеки, власної } \\
\text { оточуючих }\end{array}$ & $\begin{array}{l}\text { в) Це могло б допомогти } \\
\text { мені у подальшій освіті } \\
\text { (наприклад, якби я вступав } \\
\text { до медичного ВНЗ тощо) }\end{array}$ \\
\hline $\begin{array}{l}\text { г) Знання i } \\
\text { одержані нміння, } \\
\text { факультативу, } \\
\text { допомогли } \\
\text { скля мені } \\
\text { скласти ДПА (або ЗНО) }\end{array}$ & $\begin{array}{lr}\text { r) Мені } & \text { подобаються } \\
\text { заняття } & \text { цього } \\
\text { вчителя, тому я їх } \\
\text { відвідував би }\end{array}$ & $\begin{array}{l}\text { e) Не } \\
\text { відвідував би, } \\
\text { тому що }\end{array}$ \\
\hline
\end{tabular}




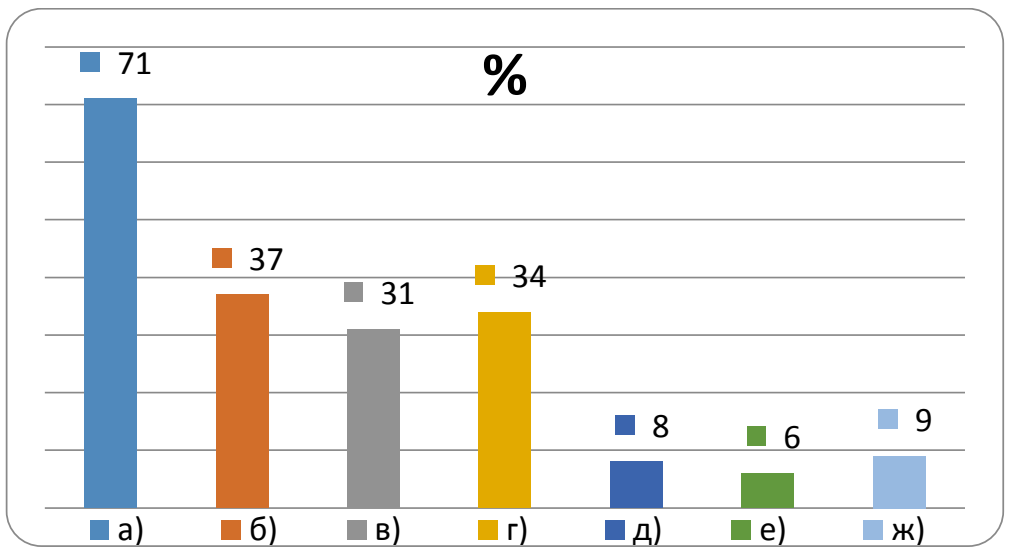

Рис.1. Результати опитування учнів

3'ясували, що 71\% опитаних учнів цікаво дізнатись про роль хімічних елементів у своєму організмі. У 9\% виявили відсутність інтересу до таких занять. При цьому $37 \%$ опитаних уважають, що вивчення окресленого питання є корисним для безпеки і здоров'я, власного й оточуючих. Отже, урахування широких пізнавальних мотивів і соціальних (бути корисним) є важливими для вмотивованого вибору учнями факультативу.

2. Працюювати з изікавими кольоровими посібниками, залучити комп'ютери до своєї роботи. Навчальний процес повинен бути повністю забезпечений засобами навчання. Це стосується навчально-методичного забезпечення, комп'ютера (як інструмента пізнання і навчальної комунікації), а також засобів, необхідних для практичних занять з хімії. Основні ідеї, покладені в розробку системи навчальнометодичного забезпечення занять факультативу, вбачаємо в такому:

$\checkmark$ різноманітність розроблених посібників за тематичними напрямами;

$\checkmark$ вичерпність $i$ иілісність навчального матеріалу посібників, що дозволяє використовувати їх як довідкові (на заняттях факультативу і на уроках);

$\checkmark$ стиль виконання: колір, лаконічність, завершеність ідеї;

$\checkmark$ залучення учнів до створення елементів наочності, що розкиває творчий потенціал учнів;

$\checkmark$ швидке реагування $і$ відображення в наочності змін у житті суспільства і природи, які потребують застосування засвоєних знань на факультативі.

Навчальні посібники, які ми пропонуємо учням для занять на факультативі, збуджують їхній інтерес до пізнання [3; 4]. Отже, повне методичне забезпечення навчального процесу є важливою умовою його успішності.

3. Працювати у групах, парах, спілкуватись з однолітками. Комунікативний складник навчального процесу $є$ важливою умовою самореалізації учня. Іноді сам вибір факультативу пов'язаний зі спілкуванням між однокласниками, учнями різних класів. При цьому вчитель не нав'язує свою думку, а організовує діалог, полілог, співпрацю учасників навчального процесу. Комп'ютерні технології покликані розширити коло навчального спілкування учнів. 
4. Навчання не заради навчання, а можливість розвиватись у процесі діяльності, а також створювати навчальний продукт, який буде корисний: для подальшого навчання; для класу, школи тощуо. Розвивальна функція факультативних занять (як навчальна i виховна) $\epsilon$, беззаперечно, важливою. Розвиток учнів відбувається у процесі їхньої діяльності і створення кінцевого освітнього продукту. Це $\epsilon$ важливою умовою формування компетентностей як зовні заданих вимог до знань і вмінь учнів. Створення кінцевого продукту формує ціннісне ставлення до хімічних знань. Кінцевий освітній продукт (від короткого повідомлення до наукового дослідження) визначає корисність одержаних знань і вмінь.

5. Покращення навчальних досягнень з хімї, допомога при складанні ДПА, $3 H O$ тощо (такий мотив виявлений у $34 \%$ опитаних учнів). $31 \%$ опитаних бажають, щоб факультатив допоміг у подальшій освіті (вступ до медичного ВНЗ тощо). Це свідчить про наявність утилітарно-практичного мотиву до вибору факультативу. Його необхідно враховувати, а тому зміст авторського факультативу «Хімічні елементи в організмі людини» сприяє розвитку знань старшокласників про хімічні елементи, що покращить навчальні досягнення учнів 3 хімії. До курсу також розроблений збірник задач, мета якого на основі матеріалу про хімічні елементи в організмі людини розвивати навички розв'язування типових задач шкільного курсу.

6. Наша мета- самореалізація. Багатий зміст факультативу допоможе широко використовувати одержані знання: на уроках хімії, біології, географії, фізики тощо; під час підготовки позакласних заходів; для участі в конкурсах, олімпіадах тощо. Створений навчальний продукт повинен сприяти самореалізації учня, а отже, його треба представити аудиторії (форми роботи: демонстрація (виставка) доробку, підготовка повідомлень, рефератів, захист проектів тощо).

7. Цей учитель уміс доводити справу до кіния. Мені подобаються його заняття. Роль учителя у вмотивованому виборі факультативу $є$ беззаперечною. Учні не відвідуватимуть заняття вчителя, який їм не подобається. Його організаторські здібності, педагогічний хист, любов до дітей i своєї праці стимулюватимуть інтерес учнів до занять факультативу.

8. Виконувати цікавий додатковий хімічний експеримент. Хімічний експеримент - специфічний для хімічного факультативу метод навчання. Його наявність $є$ обов'язковою ознакою вмотивованого вибору учнем факультативного курсу.

Розроблені критерії у їх сукупності відіграють важливу роль задля оновлення методики сучасного факультативного навчання хімії. У перспективі необхідна детальна експериментальна перевірка пропонованих критеріїв.

\section{Література}

1. Абжалов Р. Р. Деякі проблеми факультативного навчання хімії / Р. Р. Абжалов // Завдання і перспективи навчання хімії у профільній школі: Міжнародна наукова інтернет-конференція (Полтава, 18-24 квітня 2012 р.) : зб. наук. праць. Полтава : ПП Шевченко Р. В., 2012. - С. 5 - 8. 2. Абжалов Р. Міжпредметні факультативи та курси за вибором міжпредметного змісту як пріоритетний напрям навчання хімії / Роман Абжалов, Надія Чайченко // Імідж сучасного педагога. 2013. - № 6 (135).- С. 5-9. 3. Абжалов Р. Р. Назви хімічних елементів / Роман Абжалов. - Х. : Вид. група «Основа», - 2012 р. - 32 с. - (Серія «Наочно-дидактичні матеріали»). 4. Абжалов Р. Р. Хімічні елементи в організмі людини/ Роман Абжалов. - Х. : Вид. група «Основа». - 2012 р. - 32 с. 5. Бондар В. І. Дидактика / В. I. Бондар. - К. : Либідь, 2005. - 264 с. 6. Гончаренко С. У. Український педагогічний енциклопедичний словник / Семен Гончаренко. - [2-е вид., доп. й 
випр.]. - Рівне : Волинські обереги, 2011. - 522 с. 7. Кизенко В. І. Система підготовки вчителя до проведення факультативних занять / В. Кизенко // Біологія і хімія в сучасній школі. - 2012. - № 5. - С. 23 - 28. 8. Сучасний урок. Інтерактивні технології навчання : [наук.-метод. посібн.] / О. І. Пометун, Л. В. Пироженко; за ред. О. І. Пометун. - К. : Видавництво А.С.К., 2004 - 192 с. 9. Хуторской А. В. Современные педагогические инновации на уроке / А. В. Хуторской // Интернетжурнал «Эйдос» [Електронний ресурс]. - 2007.- 5 июля.- режим доступу : http://www.eidos.ru/journal/2007/0705-4.htm. 10. Чепіль М. М. Педагогічні технології : навч. посіб. / М. М. Чепіль, Н. 3. Дунник. - К. : Академвидав, 2012. $224 \mathrm{c}$.

УДК 371.3:811.161.2

Вікторія Зінченко

\section{РОБОЧИЙ ЗОШИТ ЯК ЗАСІБ ФОРМУВАННЯ МОВНО-МОВЛЕННСВОЇ КОМПЕТЕНТНОСТІ СТАРШОКЛАСНИКІВ}

Зінченко В. М. Концептуальні засади формування мовно-мовленнєвих компетентностей учнів старших класів профільної школи.

У статті визначено мету й завдання профільного курсу української мови, сформульовано концептуальні засади вдосконалення змісту й організації навчання української мови учнів старших класів профільної школи на основі системного підходу та запропоновано концепцію навчання української мови у профільних класах загальноосвітніх навчальних закладів (профіль - українська філологія).

Ключові слова: концептуальні засади, профільний курс української мови, мовно-мовленнєві компетентності, концепція навчання.

Зинченко В. М. Концептуальные основы формирования языково-речевых компетентностей учеников старших классов профильной школы.

В статье определены цели и задачи профильного курса украинского языка, сформулированы концептуальные основы усовершенствования содержания и организации обучения украинскому языку учеников старших классов профильной школы на основе системного подхода и предложена концепция обучения украинскому языку в профильных классах общеобразовательных учебных заведений (профиль - украинская филология).

Ключевые слова: концептуальные основы, профильный курс украинского языка, языково-речевые компетентности, концепция обучения.

Zinchenko V. M. Conceptual basics of the language and speech competences formation of the students from specialized high school.

The article determines objectives and problems of the Ukrainian specialization course, defines conceptual basis of the improvement of Ukrainian specialized high school educational contents and organization on the systems approach ground; suggests the language teaching conception of Ukrainian in the specialized high school classes (specialization - Ukrainian philology).

Key words: conceptual basis, Ukrainian language specialized course, language and speech competence, educational conception. 